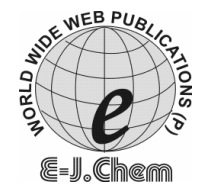

http://www.e-journals.net
ISSN: 0973-4945; CODEN ECJHAO

E-Journal of Chemistry

2010, 7(4), 1120-1132

\title{
Review
}

\section{Catalysis in Biodiesel Production by Transesterification Processes-An Insight}

\author{
P. M. EJIKEME ${ }^{*}$, I. D. ANYAOGU ${ }^{\S}$, C. L. EJIKEME", \\ N. P. NWAFOR, C. A. C. EGBUONU ${ }^{\mathbb{T}}$, K. UKOGU and J. A. IBEMESI \\ Department of Pure and Industrial Chemistry, \\ University of Nigeria, Nsukka, Nigeria. \\ ${ }^{\S}$ Department of Science Laboratory Technology, \\ Federal Polytechnic, Nasarawa, Nigeria. \\ "Department of Mathematics, "Department of Biochemistry, \\ University of Nigeria, Nsukka, Nigeria. \\ ejikemepaul13@yahoo.com
}

Received 31 July 2009; Accepted 20 September 2009

\begin{abstract}
Biodiesel is the mono-alkyl esters of long chain fatty acids derived from renewable lipid feedstock, such as vegetable oils and animal fats, for use in compression ignition (diesel) engines. The conversion of component triglycerides in oils to simple alkyl esters with short chain alcohols like methanol and ethanol amongst others is achieved mainly by transesterification. The transesterification reaction, a reversible process proceeds appreciably by the addition of catalysts, which can be acidic, basic or organic in nature, usually in molar excess of alcohol. The economy of the process depends on the type and quantity of catalyst used among other factors. The catalyst can be homogeneous or heterogeneous depending on whether it is in the same or different phase with the reactants; oils and alcohols. This paper attempts to give an insight into some of the various types of catalysts that have been used to effect the transesterification of vegetable, waste and animal oils in biodiesel production.
\end{abstract}

Keywords: Biodiesel, Transesterification, Free fatty acids, Lipase, Guanidines.

\section{Introduction}

Chemical transesterification or alcoholysis of triglycerides or the esterification of free fatty acids using short-chain alcohols in the production of alkyl esters or biodiesel was first reported $^{1}$ on August $31^{\text {st }} 1937$ in a Belgian Patent by Chavanne of the University of Brussels $^{2}$. In the early 1940 s researches that did not actually anticipate the production of alkyl esters as fuel were patented ${ }^{3-8}$. The original objective of the work was to develop a simplified method for extracting glycerol during soap production ${ }^{9}$. The glycerol was needed 
for wartime explosives production. The glycerol could be separated since it is insoluble in the esters and has a much higher density that makes settling or centrifugation a choice process in its removal.

Transesterification reaction of vegetable oils can be represented as in Scheme 1. The reaction does not proceed to any appreciable extent in the absence of catalysts or supercritical condition. Various homogeneous and heterogeneous catalysts, ranging from base, acid to enzyme ${ }^{10,11}$ as well as carbon catalysts produced from sugar starch and cellulose have been developed for use in biodiesel production.

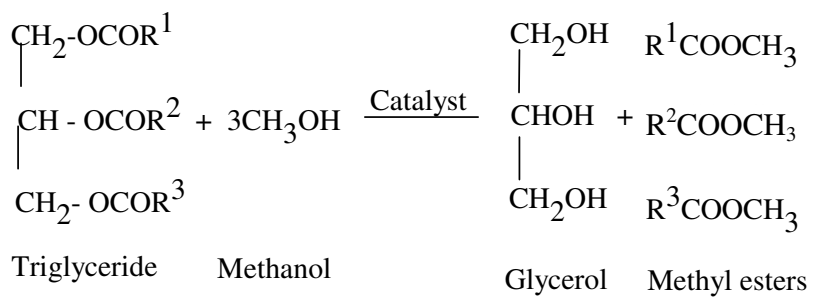

Scheme 1. A typical transesterification reaction.

\section{Different catalyst systems used in biodiesel production}

\section{Base-catalyzed processes}

Several conventional and non-conventional base-catalyzed transesterification processes have been reported in a review by Knothe et $a l^{12}$. Boiler ashes, potassium hydroxide $(\mathrm{KOH})$ amongst other catalysts were successfully used in the ethanolysis and methanolysis of palm and coconut oils with yields as high as $90 \%^{13-17}$. It has also been reported that methyl and ethyl esters with $90 \%$ yield can be obtained from palm and coconut oil from the press cake and oil mill and refinery waste with the ashes of the wastes (fibers, shell, and husks) of these two oil seeds, and with lime, clay, zeolites, $e^{1 c^{18-21}}$. Methanolysis has been reported to yield $96-98 \%$ esters when palm oil is refluxed $2 \mathrm{~h}$. Using coconut-shell ash and other ashes from the combustion of plant wastes such as fibers of palm tree that contain potassium and sodium carbonate ${ }^{22}$. Calcium oxide on magnesium oxide has been shown, at $60-63{ }^{\circ} \mathrm{C}$, to be the best catalyst system amongst potassium carbonate, sodium carbonate, iron(III) oxide, sodium methoxide, sodium aluminate, zinc, copper, tin, lead and zinc oxide in the methanol transesterification of low-erucic rapeseed oil ${ }^{23}$.

Generally, the mechanism of the base-catalysed transesterification of vegetable oils involves four steps. The first step is the reaction of the base with the alcohol, producing an alkoxide and the protonated catalyst. The second step is the nucleophilic attack of the alkoxide at the carbonyl group of the triglyceride generating a tetrahedral intermediate ${ }^{24-26}$. The third step involves the formation of the alkyl ester and the corresponding anion of diglyceride. The final step involves deprotonating the catalyst, thus regenerating the active species, which is now able to react with a second molecule of the alcohol, starting another catalytic cycle. Diglycerides and monoglycerides are converted by the same mechanism to a mixture of alkyl esters and glycerol. The above steps are summarized in Scheme 2.

The base-catalyzed transesterification of vegetable oils are reported to proceed faster than the acid- catalyzed reactions ${ }^{27}$. Because of this and the fact that the alkaline catalysts are less corrosive than acidic compounds, industrial processes usually favour base catalysts, such as alkaline metal alkoxides ${ }^{28}$ and hydroxides ${ }^{29-31}$ as well as sodium or potassium 
carbonates $^{22,32}$. Alkaline metal alkoxides (as $\mathrm{CH}_{3} \mathrm{ONa}$ for the methanolysis) are the most active catalysts. They give yields greater $98 \%$ in a relatively short reaction time of $30 \mathrm{~min}$. even at low molar concentrations of about $0.5 \mathrm{~mol} \%$, but their requirement of the absence of water makes them inappropriate for typical industrial processes in which water cannot be avoided completely ${ }^{33}$.

$$
\text { Pre-step } \quad \mathrm{OH}+\mathrm{ROH} \rightleftharpoons \mathrm{RO}^{-}+\mathrm{H}_{2} \mathrm{O}
$$

or $\mathrm{NaOR} \rightleftharpoons \mathrm{RO}^{-}+\mathrm{Na}^{+}$

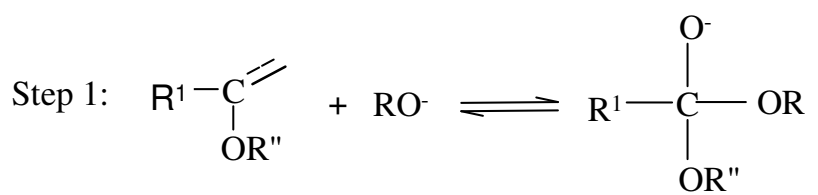

Step 2:<smiles>[R]OC([R])([R])[O+][R]</smiles>

Step 3:<smiles>[R]O[R]O[R]([R])([R])[OH2+]</smiles><smiles>[R]OC(=O)OCC(C[18O])C([R])O[R]</smiles>

$\mathrm{R}^{1}=$ Carbon chain of fatty acid, $\mathrm{R}=$ Alkyl group of alcohol

Scheme 2. Mechanism for base catalysed transesterification process.

Alkaline metal hydroxides (e.g $\mathrm{KOH}$ and $\mathrm{NaOH})$ are cheaper than metal alkoxides, but less active. Nevertheless, they are a good alternative since they can give the same high conversions of vegetable oils just by increasing the catalyst concentration to 1 or $2 \mathrm{~mol} \%$. However, even if water-free alcohol/oil mixture is used, some water is produced in the system by the reaction of the hydroxide and the alcohol. The presence of water gives rise to hydrolysis of some of the produced ester (Scheme 3), with consequent soap formation $^{33}$. In 2003, metal complexes of the type M(3-hydroxy-2-methyl-4pyrone $)_{2}\left(\mathrm{H}_{2} \mathrm{O}_{2}\right)$, where $\mathrm{M}=\operatorname{Tin}(\mathrm{Sn})$, Zinc $(\mathrm{Zn})$, Lead $(\mathrm{Pb})$ and Mercury $(\mathrm{Hg})$ were used for soybean oil methanolysis under homogeneous conditions ${ }^{34}$. The Sn complex at a molar ratio of 400:100:1 methanol:oil:catalyst gave 90\% conversion in $3 \mathrm{~h}$. while the $\mathrm{Zn}$ complex gave only $40 \%$ conversion under the same conditions. This undesirable saponification reaction reduces the ester yields and considerably makes difficult the recovery of the glycerol due to the formation of emulsions, increase in viscosity and greatly increased product separation cost. 


$$
\begin{gathered}
\mathrm{OH}_{\mathrm{OR}}+\mathrm{H}_{2}=\text { carbon chain of fatty acid } \\
\mathrm{R}=\text { alkyl group of the alcohol }
\end{gathered}
$$

Scheme 3. Hydrolysis of esters and formation of soap by the presence of water.

Potassium carbonate, used in a concentration of 2 or $3 \mathrm{~mol} \%$ gives high yields of fatty acid alkyl esters and reduces the soap formation ${ }^{35}$. This can be explained by the formation of bicarbonate instead of water (Scheme 4), which does not hydrolyze the esters. There are other heterogeneous base catalysts which have been tested with promising results ${ }^{36,37}$. Also, solid bimetallic $\mathrm{Sn}-\mathrm{Ni}^{38}$, exchange resins and zeolites ${ }^{39,40}$, organometallic compounds ${ }^{41}$ and mixed oxides ${ }^{42-44}$ have been developed and used in transesterification reactions. In addition, $\mathrm{P}\left(\mathrm{RNCH}_{2} \mathrm{CH}_{2}\right)_{3} \mathrm{~N}^{45}$, multifuntionalized $^{46}$ as well as organosulphonic acid functionalized mesoporous silicas ${ }^{47}$, all of which for industrial applications require high temperature and pressure are available.

$$
\begin{gathered}
\mathrm{K}_{2} \mathrm{CO}_{3}+\mathrm{ROH} \rightleftharpoons \mathrm{ROK}+\mathrm{KHCO}_{3} \\
\mathrm{R}=\text { alkyl group of the alcohol }
\end{gathered}
$$

Scheme 4. Equation of reaction for bicarbonate formation.

The base-catalyzed reaction is most often used because:

* It uses low temperature $\left(60{ }^{\circ} \mathrm{C}\right)$ and pressure (20Psi) processing.

* It achieves high conversion (98\%) with minimal side reactions and low reaction time.

* Conversion to methyl ester is direct with no intermediate steps.

\section{Shortcomings of homogeneous alkali catalyzed processes}

Reports already reviewed showed that base-catalyzed transesterification of vegetable oils results in good yields of the esters. Nevertheless, there are obvious problems encountered by their use. Some of these problems have been identified to include:

- High energy demand

- Post-reaction treatment to remove the catalyst from the product-biodiesel

- Interferences occasioned by the presence of free fatty acid and water during the reaction

- Difficulty in the recovery of glycerol after the reaction and

- Post-reaction treatment of the alkaline waste-water to obviate the environmental effects of its disposal

The development of acid and heterogeneous catalyst systems, some of which run in continuous reactors, have addressed many of these problems which ordinarily meant higher production costs and less economic viability relative to petroleum-based diesel.

\section{Acid-catalyzed processes}

The mechanism of the acid-catalyzed transesterification of vegetable oils is as shown in Scheme 5 for a monoglyceride. The protonation of the carbonyl group of the ester leads to the carbocation which after a nucleophilic attack of the alcohol produces the tetrahedral intermediate. This in turn eliminates glycerol to form the new ester, and to regenerate the catalyst. The mechanism can be extended to $d i$ - and triglycerides ${ }^{48}$. Carboxylic acids can be formed by reaction of the carbocation with water present in the reaction mixture. This suggests that an acid-catalyzed transesterification should be carried out in the absence of water, in order to avoid the competitive formation of carboxylic acids, which reduce the yield of alkyl esters. 


$$
\begin{gathered}
\mathrm{R}^{\prime \prime}=\frac{\mathrm{OH}_{\mathrm{OH}}}{\text { glyceride }} \\
\mathrm{R}^{\prime}=\text { carbon chain of fatty acid, } \mathrm{R}=\text { alkyl group of the alcohol }
\end{gathered}
$$

Scheme 5. A typical mechanism of acid catalyzed transesterification of vegetable oils.

The transesterification process in biodiesel production is catalyzed by Bronsted acids like $\mathrm{HCl}, \mathrm{BF}_{3}, \mathrm{H}_{3} \mathrm{PO}_{4}, \mathrm{H}_{2} \mathrm{SO}_{4}$ and sulphonic acids ${ }^{49,50}$. Preferably, sulphonic and sulphuric acids are mostly used. These catalysts give very high yields in alkyl esters, but the reactions are slow, requiring typically, temperatures above $100{ }^{\circ} \mathrm{C}$ and from $3-48 \mathrm{~h}$ to reach complete conversion $^{51-56}$. Freedman et al showed that the methanolysis of soybean oil, in the presence of $1 \mathrm{~mol} \%$ of $\mathrm{H}_{2} \mathrm{SO}_{4}$, with an alcohol/oil molar ratio of $30: 1$ at $65{ }^{\circ} \mathrm{C}$, takes $50 \mathrm{~h}$ to reach complete conversion of the vegetable oil $(>99 \%)$, while the butanolysis (at $117^{\circ} \mathrm{C}$ ) and ethanolysis $\left(\right.$ at $78{ }^{\circ} \mathrm{C}$ ) using the same quantities of catalyst and alcohol take $3 \mathrm{~h}$ and $18 \mathrm{~h}$, respectively ${ }^{27}$.

Peter et al. ${ }^{57}$ studied the methanolysis of palm oil in a 6:1 molar ratio of methanol to oil using the following metal salts of amino acids; cadmium, cobalt, copper, iron, lanthanum, nickel and zinc. Arginate of zinc was shown to result in the highest yield and the reasonable rate of reaction estimated to be obtained at temperatures higher than $130{ }^{\circ} \mathrm{C}$. Report also indicated that soybean oil can be transesterified in methanol using sulphated zirconia-alumina and tin oxide as well as tungstated zirconia-alumina acid catalysts, though the latter was adjudged most effective as it gave $90 \%$ conversion in $20 \mathrm{~h}$ at $250{ }^{0} \mathrm{C}^{58}$. Other sulphated compounds of zirconium have also been studied with varying results ${ }^{59-60}$. New solid acid/base catalysts as well as metal oxides have also been used in the transesterification process ${ }^{61-64}$.

Reaction rates in acid-catalyzed processes may be increased by the use of larger amounts of catalyst. Typically, catalyst concentrations in the reaction mixture have ranged between 1 and $5 \mathrm{wt} \%$ in most academic studies using sulphuric acid $^{27}$. Canakci and Van Gerpen ${ }^{65}$ used different amounts of sulphuric acid (1,3 and $5 \mathrm{wt} \%)$ in the transesterification of grease with methanol. In these studies, a rate enhancement was observed with the increased amounts of catalyst and ester yield went from 72.7 to $95.0 \%$ as the catalyst concentration was increased from 1 to $5 \mathrm{wt} \%$. The dependence of reaction rate on catalyst concentration has been further verified by the same authors and other groups ${ }^{66-67}$. A further complication of working with high acid catalyst concentration becomes apparent during the catalyst neutralization process, which precedes product separation. Since $\mathrm{CaO}$ addition during neutralization is proportional to the concentration of acid needed in the reactor, high acid concentration leads to increased $\mathrm{CaO}$ cost, greater waste formation, and higher production cost.

The liquid acid-catalyzed transesterification process does not enjoy the same popularity in commercial applications as its counterpart, the base-catalyzed process. The fact that the homogeneous acid-catalyzed reaction is about 4000 times slower than the homogeneous base-catalyzed reaction has been one of the main reasons ${ }^{68}$. However, acid-catalyzed transesterification holds an important advantage with respect to base-catalyzed ones; 
the performance of the acid catalyst is not strongly affected by the presence of free fatty acids in the feedstock. Thus, a great advantage with acid catalysts is that they can directly produce biodiesel from low-cost feedstocks, generally associated with high free fatty acid concentrations. A two step esterification process in which the free fatty acid is converted to fatty acid methyl esters in an acid-catalyzed treatment followed by base-catalyzed process has been proposed ${ }^{66}$.

In the transesterification of triglyceride feedstock using acid catalysts, Mittelbach et al. ${ }^{69}$ compared the activities of a series of layered aluminosilicates with sulphuric acid for the transesterification of rapeseed oil. These researchers used an initial molar ratio of 30:1 alcohol-to-oil and 5wt\% catalysts. Among the catalysts tested, sulphuric acid showed the highest activity. The solid catalysts showed varied activities depending on reaction conditions. The most active catalysts were activated by sulphuric acid impregnation. For instance, activated montmorillonite KSF showed a $100 \%$ conversion after $4 \mathrm{~h}$ of reaction at $220{ }^{\circ} \mathrm{C}$ and 52 bar. However, leaching of sulphate species compromised the re-usability of this clay. Thus, to maintain clay activity at constant values, sulphuric acid re-impregnation had to be carried out after each run. It is also likely that some degree of homogeneous catalysis was taking place due to sulphuric acid leaching, they concluded.

Kaita et al. designed aluminum phosphate catalysts with various metal-to-phosphoric acid molar ratios and used these materials for the transesterification of kernel oil with methanol ${ }^{70}$. According to the authors, durable and thermostable catalysts were obtained with good reactivity and selectivity to methyl esters. However, the use of these materials still needed high temperatures $\left(200{ }^{\circ} \mathrm{C}\right)$ and high methanol to-oil molar ratios $(60: 1)$ in order to be effective.

In a related study, Waghoo et al. ${ }^{71}$ reported on the transesterification of ethyl acetate with several alcohols over hydrous tin oxide to obtain larger esters. Linear and aromatic alcohols were tested in a temperature range of $170-210{ }^{\circ} \mathrm{C}$. All reactions were completely reflective for transesterification. In particular, this catalyst presented an appreciable activity for reactions involving $n$ - butyl alcohol, $n$-octyl alcohol and benzyl alcohol.

Amberlyst-15 has also been studied for transesterification reactions. However, mild reaction conditions are necessary to avoid degradation of the catalyst. At a relatively low temperature $\left(60{ }^{\circ} \mathrm{C}\right)$, the conversion of sunflower oil was reported to be only $0.7 \%$ when carrying out the reaction at atmospheric pressure and a 6:1 methanol-to-oil molar ratio ${ }^{72}$. Also, hydrochloric, organic, sulfonic, formic, acetic and nitric acids have been investigated by other authors ${ }^{33,73-75}$.

\section{Variables affecting the acid-catalyzed processes}

The acid-catalyzed process is thought to be more suitable for the production of biodiesel from low feedstocks (used frying oil, waste animal fat), mainly because of the fact that these feedstocks contain greater amounts of free fatty acids (FFAs ${ }^{76}$. The base- and acidcatalyzed transesterification processes were compared with respect to the FFAs content of the feedstock. The greater tolerance of an acid catalyst to the FFA content compared to an alkaline catalyst was confirmed in a report by Canakci and Van Gerpen ${ }^{65}$. They also showed that acid catalyzed reactions are more susceptible to water content of the feedstock than the base-catalyzed process and that the presence of more than $0.5 \%$ water in the oil will decrease the ester conversion to below $90 \%{ }^{66,77-78}$. The fact that the water content is more crucial in acid catalysis than in alkaline catalysis is mainly caused, according to Siakpas et $a l^{76}$, by the greater affinity of water by sulphuric acid, which will lead to the acid catalyst preferentially interacting with water rather than alcohol with the consequent deactivation of the catalyst. Also, there is evidence that large quantities of acid catalyst in biodiesel production may lead to ether formation by alcohol dehydration ${ }^{79}$ and the consequent high 
use of calcium oxide in the acid neutralization after production with its attendant high production cost and waste generation. It has been suggested that acid-catalyzed transesterification achieves greater and faster conversions at high alcohol concentrations ${ }^{74}$.

\section{Non-ionic base-catalyzed processes}

Schuchardt et al. ${ }^{80}$ in a comprehensive review had reported that in order to obtain milder reaction conditions and to simplify manipulations, a great number of organic bases have been developed and used as catalyst or reactant for organic synthesis. Among these bases, amines such as triethylamine; piperidines like 1,2,2,6,6,-pentamethyl piperidine; pyridines like 2,6ditert-butylpyridine $^{81,82}$ and 4-dimethyl-amino pyridine (DMAP) ; $^{83}$ amidines such as 1,8diazabicylo $(5,4,0)$ undec-7-ene (DBU) and 1,5diazabicyclo(4,3,0)non-5-ene (DBN) ${ }^{81}$; guanidines such as 1,5,7-triazabicyclo $(4,4,0)$ dec-5-ene $(\mathrm{TBD})^{84}, 1,1,3,3$-tetramethylguanidine $(\mathrm{TMG})^{85}$, 1,1,2,3,3-pentabutylguanidine ${ }^{86}$ (PBG), 1,3-diphenylguanidine ${ }^{87}, 1,2,3$-triphenylguanidine ${ }^{88}$ and amino- and nitroguanidines ${ }^{89}$; triamino(imino)phosphoranes such as tert-butyl imino-2,2diethylamino-1,3-dimethyl-perhydro-1,3,2-triazaphosphorane (BEMP) ${ }^{90}$ and tris(dimethylamino) methyliminophosphorane $\left(\mathrm{Me}_{7} \mathrm{P}\right)$, shown in Scheme 6 are frequently used in organic synthesis ${ }^{80}$. The activity and efficiency of such non-ionic bases as catalysts for the transesterification of vegetable oils were studied. In a first series of studies, according to Schuchardt $e t a l^{80}$, the catalytic activity of some guanidines was compared to that observed using other bases such as the amidines, DBU and DBN, and the triamino (imino) phosphoranes, BEMP and $\mathrm{Me}_{7} \mathrm{P}$. It was observed that TBD, even if applied at only $1 \mathrm{~mol} \%$ produces more than $90 \%$ of methyl ester after $1 \mathrm{~h}$. Using the other bases, under the same experimental conditions, the yields were not higher than $66 \%$. The order of the catalytic activity is not directly related to the relative basicity of these compounds, since BEMP and $\mathrm{Me}_{7} \mathrm{P}$ should be the more efficient catalysts, followed by TBD. However, the guanidines are more active catalysts and the activity follows their relative basicity.

Schuchardt ${ }^{80}$ inferred that according to the observed results and to the mechanism of the base-catalyzed transesterification, it seemed that the good performance of TBD, when compared to $\mathrm{BEMP}$ and $\mathrm{Me}_{7} \mathrm{P}$, is related to its kinetic activity. The catalytic site (unshared electron pair of the $\mathrm{SP}^{2} \mathrm{~N}$ ) of TBD is practically unhindered allowing an easy access of the methanol for proton transfer, while the steric hindrance shown by the triamino (imino) phosphoranes is so significant that they are practically inert to alkylating agents, such as isopropyl bromide, as well as extremely resistant to react with thionyl chloride and thiophosgene ${ }^{91}$.<smiles>[AlH]N1CCCN2CCCN=C12</smiles>

TBD<smiles>C1CCC2=NCCCN2CC1</smiles>

DBU<smiles>C1CN=C2CCCN2C1</smiles>

DBN<smiles>CCN(CC)P1(=N)NCCCN1</smiles>

BEMP<smiles>CN=P(NC)(N(C)C)N(C)C</smiles>

$\mathrm{Me}_{7} \mathrm{P}$<smiles>CN1CCCN2CCCN=C12</smiles>

MTBD<smiles>CCCCCCCNC(NC(CC)CCC)NC1CCCCC1</smiles>

DCOG<smiles>C1CCC(NC(NC2CCCCC2)NC2CCCCC2)CC1</smiles>

TCG

Scheme 6. Structures of some non-ionic bases ${ }^{80}$. 
In a second series of studies ${ }^{80}$, the catalytic activity of TBD was compared to that observed for typical industrial catalysts $\left(e . g \mathrm{NaOH}\right.$ and $\mathrm{K}_{2} \mathrm{CO}_{3}$ ). The reaction yields obtained with TBD were close to those observed with $\mathrm{NaOH}$ and no undesirable by-products such as soaps (easily formed when alkaline metal hydroxides are used) were observed. When compared to potassium carbonate, TBD was always more active, even at low molar concentrations. Although TBD is less active than sodium methoxide (at only $0.5 \%, \mathrm{CH}_{3} \mathrm{ONa}$ produces more than $98 \%$ of methyl esters after $30 \mathrm{~min}$ ), its use does not require any special condition. Due to the excellent performance of TBD in the transesterification of vegetable oils, the catalytic activity of other alkylguanidines was also investigated, in order to establish and understand all factors that may affect their catalytic properties.

In a third series of studies, the catalytic activity of several alkylguanidines was compared $^{92}$. According to the authors, TBD was always the most active, however, 1, 3dicyclohexyl -2- octylguanidine (DCOG); 1, 1, 1, 2, 3, 3- pentamethylguanidine; 7- methyl1, 5, 7-triazabicyclo $(4,4,0)$ dec-5-ene (MTBD) and 1, 2, 3- tricyclohexyl guanidine (TCG), also showed a good catalytic performance. The activity order of the catalysts TBD $>$ TCG $>$ DCOG $>$ MTBD > PMG corresponds to their relative base strength, which is increased by structural factors such as number and type of subsistent (cyclic or acyclic chain). The excellent performance of DCOG and TCG is also assigned to the high symmetry of their guanidine cations, as observed earlier for the symmetric 1, 2, 3- trimethylguanidine ${ }^{93}$.

Results obtained in the transesterification of soybean oil with methanol show that 1,2 , 3, 4, 5- pentacyclohexyl biguanidine (PCBG) is even more active than TCG, as an $82 \%$ yield of methyl esters is obtained with PCBG after $1 \mathrm{~h}$, compared to 69\% with TCG under the same conditions ${ }^{94}$.

\section{Lipase-catalyzed processes}

Due to their ready availability and the ease with which they can be handled, hydrolytic enzymes have been widely applied in organic synthesis. They do not require any coenzymes, are reasonably stable, and often tolerate organic solvent ${ }^{76}$. Their potential for regioselective and especially for enantioselective synthesis makes them valuable tools ${ }^{95}$. Immobilized Candida Antarctica lipase has been used for ethyl esterification of docosahexanoic acid ${ }^{95}$ and latter used to effect over $98.5 \%$ fatty acid methyl ester conversion ${ }^{96,97}$.

Although the enzyme-catalyzed transesterification processes are not yet commercially developed, new results have been reported in recent articles and patents ${ }^{98}$. A solution to the inhibition of enzyme activity by high concentration of methanol as well as water generated during the reaction have been proffered by many authors ${ }^{96,99-101}$ to include carrying out the reaction with immobilized enzymes and the use of multiple stages. The common aspects of these studies consist in optimizing the reaction conditions (solvent, temperature, $\mathrm{pH}$, type of microorganism which generates the enzyme, etc.) in order to establish suitable characteristics for an industrial application. However, the reaction yields as well as the reaction times are still unfavorable compared to the base- catalyzed reaction systems, though Shimada and co-workers reported that the stepwise addition of methanol gave $98 \%$ conversion of oil to methyl ester with an amazing re-use of the immobilized enzyme for 50 times $^{98}$. Several reports exist on lipase catalyzed transesterification process with extracellular and intracellular lipases as catalyst in either aqueous or non-aqueous systems ${ }^{99-104}$. The incubation of Candida antarctica lipase consecutively in methyl ester (oleate) for $30 \mathrm{~min}$ and in soybean oil for $12 \mathrm{~h}$ has been reported to lead to a dramatic increase in the efficiency of the enzyme, giving almost $100 \%$ conversion $^{109}$. While Du t $a l 1^{10}$ reported lipase-catalyzed transformation of soybean oil for biodiesel 
production with different acyl acceptors, others ${ }^{111-113}$, reported the use of other enzymes like Chlorella vulgaris and Candida cylindracae in the conversion of other oils to biodiesel.

The variables affecting the use of enzymes like temperature, solvent, water content, immobilization or free enzyme use as well as $\mathrm{pH}$ and time of reaction have been studied with a view to obtaining optimum conditions for improved conversions ${ }^{114-116}$.

\section{Use of organic catalyst from carbonized sugar}

Japanese researchers have devised a low-cost, ecologically friendly solid catalyst for the production of biodiesel: a carbon catalyst produced from sugar, starch or cellulose ${ }^{117}$. The separation of the liquid catalyst from the reaction mixture is costly and wasteful. Other catalysts such as nafion or sulphonated naphthalene are either expensive or offer less or rapidly diminishing catalytic activity.

The researchers avoided all those issues by devising a mechanism to incompletely sulphonate (treat with sulphuric acid) carbonized natural organic material such as sugar, starch or cellulose to prepare a more robust solid catalyst. Incomplete carbonization of these natural products results in a rigid carbon material. The team found that sulphonation of this material generates a stable solid with a high density of active sites, enabling the inexpensive preparation of a high performance catalyst. The team found that the activity of the solid sulphonated carbon catalyst is more than half that of a liquid sulphuric catalyst ${ }^{117}$.

\section{Conclusion}

The industrial homogeneous catalysts will have to be substituted in the near future by heterogeneous catalysts due to environmental reasons. Good strong-base heterogeneous catalysts are still in development. One possibility would be the use of zeolites with strong basic sites. Enzymes, especially lipases, are also becoming catalysts of choice in transesterification reactions in biodiesel production despite their cost. This is because they offer some advantages as far as pretreatment of process streams are concerned. Efforts are being made by scientists to develop novel catalysts that will offer best environmental practices as well as relatively good cost.

\section{References}

1. Knothe G, Historical Perspectives on Vegetable Oil-Based Diesel Fuels, Inform, 2001, 12(1), 1103-1107.

2. Chavan G, Procedure for the Transesterification of Vegetable Oils for their Uses as Fuels, Belgian Patent No., 1937, 422877.

3. Bradshaw G B, New Soap Process, Soap, 18 (May), 1942, 23-24, 69-70.

4. Bradshaw G B and Mealy W C, Process of Making Pure Soaps, U. S. Patent No. 2, 1942, 271, 619 .

5. Bradshaw G B and Meuly W C, Preparation of Detergents, U. S. Patent No. 2, 1944, 360, 844.

6. Arrowsmith C J and Ross J, Treating Fatty Materials, U. S. Patent No. 2, 383, 580.

7. Allen H D, Rock G and Kline W A, Process for Treating Fats and Fatty Oils, U. S. Patent No. 1945, 2, 383-579.

8. Walter R T, Process of Treating Fatty Glycerides, U. S. Patent No. 2, 1945, 383- 632.

9. Van Garpen J, Fuel Process Technol., 2005, 86, 1097-1107.

10. Freedman B and Pryde E H, Fatty Esters from Vegetable Oils for use as a Diesel Fuel. In: Proceedings of the International Conference on Plant and Vegetable Oils as Fuels, 1982, 117-122. 
11. Komers K, Stloukal R, Machek J and Skopal F, Eur J Lipid Sci Technol., 2001, 103, 363-371

12. Knothe G, Dunn R O and Bagby M O "Biodiesel: The Use of Vegetable Oils and Their Derivatives as Alternative Diesel Fuels" in Fuels and Chemicals from Biomass, ACS, Washington, DC, USA, 1997, 172-208

13. Graille J, Lozano P, Pioch D and Geneste P, Oleagineux, 1986, 41, 457-464.

14. Encinar J M, Gonzalez J F, Rodriguez J J and Tejedor A. Energy Fuels, 2002, 16, 443-450.

15. Ejikeme P M, J Chem Soc Nigeria, 2008, 33(1), 145-149.

16. Ejikeme P M, Waste Vegetable Oils as Alternative to Diesel Fuel in Compression Ignition Engines, Book of Proceedings, International Workshop on Renewable Energy for Sustainable Development in Africa, $29^{\text {th }}$ July to $1^{\text {st }}$ August 2007, NCERD, UNN 2007.

17. Ejikeme P M, Egbuonu C A C and Anyaogu I D, Fatty Acid Methyl Esters of Melon Seed Oil, Characterization for Potential Fuel Applications, Book of Proceedings, Coalcity Chem, Enugu-Nigeria, 2008,

18. Graille J, Lozano P, Pioch D, Geneste P and Guida A, Oleagineux, 1982, 37, 421-424.

19. Sasidharan A and Kumar R, J Mol Catal A Chem., 2004, 210, 93-98.

20. Bandger B P, Uppalla L S and Sadavarte V S, Green Chem., 2001, 3, 39-41.

21. Ponde D E, Deshpande V H, Bulbule V J, Sudalai A and Gajare A S, J Org Chem., 1998, 63, 1058-1063.

22. Graille J, Lozano P, Pioch D and Geneste P, Oleagineux, 1985, 40, 271-276.

23. Peterson G R and Scarrah W P, J Am Oil Chem Soc., 1984, 61, 1593-1597.

24. Taft R W, Jr, Newman M. S and Verhoek F H, J Am Chem Soc., 1947, 72, 4511.

25. Guthrie J P, J Am Chem Soc., 1991, 113, 3941.

26. Meher L C, Vidya D and Naik S N, Technical Aspects of Biodiesel Production by Transesterification- A Review, Renewable and Sustainable Energy Reviews. 2006, 10(3), 248-268.

27. Freedman B, Butterfield R O and Pryde E H, J Am Oil Chem Soc., 1986, 63, 1375.

28. Schwab A W, Bagby M O and Freedman B, Fuel, 1987, 66, 1372.

29. Aksoy H A, Becerik I, Karaosmanoglu F, Yamaz H C and Civelekoglu H, Fuel, 1990, 69, 600 .

30. Gryglewiez S, Applied Catalysis A: General, 2000, 192, 23-28.

31. Albis Arrieta A R, Parra Garrido J A and Sanchez Castellanous F J, Ing Investig., 2005, 25(2), 71-77.

32. Hirano et al. United States Patent No. 6090959, Methods of Producing Fatty Acid and Lower Alkyl Ester from Fats and Oils, July, 2000, 18.

33. Freedman B, Pryde E H and Mounts T L, J Am Oil Chem Soc., 1984, 61(10), 1638-1643.

34. Abreu F R, Lima D G, Hamu E H, Einloft S, Rubim J C and Suarez P A Z, J Am Chem Soc., 2003, 80, 601.

35. Filip V, Zajic V and Smidrkal J, Rev Fr Corps Gras., 1992, 39, 91.

36. Kim H J, Kang B S, Kim M J, Park Y M, Kim D K, Lee J S and Lee K Y, Catalysis Today, 2004, 93, 315-320.

37. Gryglyewicz, Biores Technol., 1999, 70(3), 249-253.

38. Uresta J, Ramirez A, Martinez C and Vargas L, Revista Palmas, 2000, 21(1), 293-305.

39. Leclereq E, Finiels A and Moreau C, J Am Oil Chem Soc., 2001, 78(11), 1161-1169.

40 Reis S C M, Reid M G, Nascimento R S V, Lachter E R, Abstracts of the $12^{\circ}$ Congresso Brasileiro de Catalise, Angra dois Reis, Brazil, 2003. 
41. Gheorghiu, United States Patent No. 5532392, Process for the Preparation of Methyl Fatty Acid Esters Starting from Natural Oil or Fat, Methyl Esters obtained in this way and use thereof, July, 1996, 2.

42. Monteriro R S and Cruz R S, Abstracts of the $27^{\mathrm{a}}$ Reuniao Annual da Sociedade Brasileira de Quimica and XXVI Congresso Latinoamericano de Quimica, Savador, Brazil, 2004.

43. Bournaya L, Casanavea D, Delfortb B, Hillionb G and Chodorgec J A, 2005. Catalysis Today, 2005,106,190-192.

44. Stern R, Hillion G, Rouxel J J and Leporq S, 1999. Process for the Production of Esters from Vegetable Oils or Animal Oils Alcohols. United State Patent No. 5908946, 1 June 1999.

45. Ilankumaran P and Verkade J G, J Org Chem., 1999, 64, 3086-3089.

46. Mbaraka I K and Shanks B H, J Catal., 2005, 229, 365-373.

47. Mbaraka I K, Radu D R, Lin V S.Y and Shanks B H, J Catal., 2003, 219, 329-336.

48. Stoffel W, Chu F and Ahrens E H, J Anal Chem., 1959, 31, 307.

49. Stern R and Hillion G, Eur P Appl EP 1990, 356, 317.

50. Formo M W, J Am Oil Chem Soc., 1954, 31(11), 548-559.

51. Zheng S, Kates M, Bube M A and McLean D D, Biomass Bioenergy, 2006, 30(3), 267-272.

52. Zhang Y, Bube M A, McLean D D and Kates M, Biores Technol., 2003, 89(1), 1-16.

53. Jeromin L, Pekkert E and Wolmann G, Process for the Pre-esterififcation of Free Fatty Acids in Fats and Oils, U. S. Patent No. 4, 1987, 698,186.

54. Guan G, Kusakabe K, Sakurai N and Moriyama K, Fuel, 2009, 88(1), 81-86; DOI: 10.1016/j.fuel.2008.07.026.

55. Nye M J and Southwell P H, Esters from Rapeseed Oil as Diesel Fuel. In Vegetable Oils Diesel Fuel: Seminar III ARM-NC-28; Bagby M O and Pryde E H; Eds, US Dept. of Agric, Peoria, IL, 1983, p. 78.

56. Harrington K J and 'Arcy-Evans C D D, Ind Eng Chem Prod Res Dev., 1985, 24, 314-318.

57. Peters S K F, Ganswindt R, Neuner H P and Weinder E, Eur J Lipid Sci Technol., 2002, 104, 324.

58. Furuta S, Matsuhashi H and Arata K, Catal Commun., 2004, 5,721.

59. Furuta S, Matsuhashi H and Arata K, Appl Catal A., 2004, 269, 187-191.

60. Matsuhashi H, Miyazaki H, Kawamura Y, Nakamura H and Arata K, Chem Mater., 2001, 13, 3038-3042.

61. Cantrell D G, Gillie L J, Lee A F and Wilson K, Appl Catal A., Gen., 2004, 287, 183-190.

62. Karmee S and Chadha A, Biores Technol., 2005, 96, 1425-1429.

63. Satoshi F, Hiromi M and Kazushi A, Catal Commun., 2004, 5, 721-723.

64. Suppes G J, Dasari M A, Doskocil E J, Mankidy P J and Goff M J, Appl Catal A Gen., 2004, 257, 213-223.

65. Canakci M and Van Garpen J, Trans ASAE, 1999, 42(5), 1203-1210.

66. Canakci M and Van Garpen J, Trans ASAE, 2001a , 44(6), 1429-1436.

67. Crabba E, Nolasco-Hipolito C, Kobayashi G, Sonomoto K and Ishizaki A, Biodiesel Production from Crude Palm Oil and Evaluation of Butanol Extraction and Fuel Properties, Process Biochemistry, 2001, 37(1), 67-71; DOI: 10.1016/S00329592(01)00178-9. 
68. Srivatava A and Prasad R, Renewable and Sustainable Energy Rev., 2000, 4, 111-133.

69. Mittelbach M, Silberholz A and Koncar M, In Novel Aspects Concerning Acid-catalyzed Alcoholysis of Triglycerides Oils-Fats-Lipids 1995, Proceedings of the $21^{\text {st }}$ World Congress of the International Society for Fats Research, the Hague, October 1995, 1996j 1996; pp 497-499.

70. Kaita J, Mimura T, Fukuoda N and Hattori Y, Catalysts for Transesterification, U.S. patent 6, 2002, 407, 269, June 18, 2002.

71. Waghoo G, Jayaram R V and Joshi M V, Synth Commun., 1999, 29(3), 513-520. DOI: $10.1080 / 003979199008085794$

72. Vicente G, Coteron A, Martinez M and Aracil J, Ind Crops Products, 1998, 8, 29-35.

73. Vicente G, Martinez M and Aracil J, Biores Technol., 2004, 92(3), 297-305.

74. Lotero E, Liu Y, Lopez D E, Suwannakarn K, Bruce D A and Goodwin G J, Ind Eng Chem Res., 2005, 44, 5353-5363.

75. Goff M J, Bauer N S, Lopes S, Sutterlin W R and Suppes G J, J Am Oil Chem Soc., 2004, 81(4), 415-420.

76. Siakpas P, Karagiannidis A and Theodoseli M, Biodiesel Feedstock, Production and Uses, In World Sustainable Energy Days, 2006, 1-3 March, Wels/Austria, Electronic Proceedings in CD-ROM, Editor: O. Oe. Energiesparverband.

77. Canakci M and Gerpen J V, Trans ASAE, 2001b, 42(2), 1565-1572.

78. Canakci M and Gerpen J V, A Pilot Plant to Produce Biodiesel from High Free Fatty Acid Feedstocks, 2001 ASAE Annual Intl. Meeting, Paper No. 016049, Sacramento, California.

79. Keyes D B, Ind Eng Chem., 1932, 24(10), 1096-1103.

80. Schuchardt U, Sercheli R and Vargas R M, J Braz Chem Soc., 1998, 9(3), 1-25.

81. Resck I S, Quimica Nova, 1994, 17, 317

82. Hofle G, Steglich W and Vorbruggen H, Angew Chem Intl Ed Engl., 1978, 17, 569.

83. Otera J, Chem Rev., 1993, 93, 1449.

84. Berry D J, Digiovanna C V, Metrick S S and Murugan R, ARKIVOC, 2001, 2, 944-964.

85. Flynn K G and Nenortas D R, J Org Chem., 1963, 28, 3527

86. Barcelo G, Grenonillat D, Senet J P and Senny E G, Tetrahedron, 1990, 46,1839

87. Khorana H G, Chem Rev., 1953, 53, 145.

88. Smith P A S. In The Chemistry of the Open Chain Nitrogen Compounds: Benjamin: New York, 1965, Vol.1, Cap VI, p. 277

89. Short J H, Biermacher U, Dunnigan D A and Leth T D, J Med Chem., 1963, 6, 275.

90. Schwesingner R, Chimia., 1985, 39, 269

91. Schuchardt U, Vargas R M and Gelbard G, J Mol Catal., 1995, 99, 65.

92. Angyal S J and Warburton W K, J Chem Soc., 1951, 2492.

93. Xavier C P M, Sercheli R, Vargas R M, Schuchardt U, $9^{\circ}$ Congresso Brasileiro de Catalise (Instituto Brasileiro de Petroleo), 1997.

94. Drauz K, Waldman H and Sauerbrei B, In Applied Homogeneous Catalysis with Organometallic Compounds. Comils B, Herrman W A, Ed.; VCH Verlags Gessellschaft, Weinheim, 1996, 2, 769.

95. Shimada Y, Watanabe Y, Sugighara A, Baba T, Ooguri T, Moriyana S, Tarai T and Tominaga Y, J Biosci Bioeng., 2001, 92(1), 19-23.

96. Hsu A F, Jones K, Foglia T A and Marmer W N, Biotechnol Appl Biochem., 2002, 36(3), 181-186.

97. Watanabe Y, Pinsirodom P, Nagao T, Kobayashi T, Nishida Y, Takagi Y and Shimada Y, J Am Oil Chem Soc., 2005, 82(11), 825-831.

98. Posorske L H, J Am Oil Chem Soc., 1984, 61, 1758. 
99. Belafi-bako K, Kovacs F, Gubicza L and Hancsok J, Biocatalysis Biotrans., 2002, 20(6), 437-439.

100. Shimada Y, Watanabe Y, Sugighara A and Tominaga Y,J Mol Catal B Enzym., 2002, 17, 133-142.

101. Watanabe Y, Shimada Y, Sugighara A and Tominaga Y, J Mol Catal B Enzymatic., 2002, 17, 151-155.

102. Y Shimada, Y Watanabe, T Samukawa, A Sugighara, H Noda, H Fukuda and Tominaga Y, J Amer Chem Soc., 1999, 76, 789.

103. Du W, Xu Y and Liu D, Biotechnol Appl Biochem., 2003, 38, 103-106.

104. Nelson L A, Foglia T A and Marner W N, J Am Oil Chem Soc., 1996, 73(8), 1191-1195.

105. Soumanou M M and Bornscheuer U T, Enzyme Microb Technol, 2003, 33, 97.

106. Shimada Y, Watanabe Y, Samukawa T, Sugihara A, Noda H, Fukuda H and Toninaga Y, J Am Oil Chem Soc., 1999, 76, 789.

107. de A P, Vieira A, da Silva M A P and Langone M A P, Latin Am Appl Res., 2006, 36, 283-288.

108. Nelson L, Foglia T A and Marmer W N, INFORM, 1995, 6, 509-510.

109. Samukawa T, Kaieda M, Matsumoto T, Ban K, Kondo A, Shimada Y, Noda H and Fukuda H, J Biosci Bioeng., 2000, 90, 180.

110. Du W, Xu Y Y, Liu D H and Zeng J, J Mol Catal B. Enzym., 2004, 30, 125-129.

111. Scragg A H, Morrison J and Shales S W, Enzyme Microb Technol., 2003, 33, 884-889.

112. Karl-Erich J and Thorsten E, Curr Opin Biotechnology, 2002, 13, 390-397.

113. Vanessa L P and Park E Y, Enzyme Microb. Technol., 2004, 34, 270-277.

114. Soumanou M and Bornscheuer U T, Enzyme Microb Technol., 2003, 33, 97.

115. Nadir D and Bulent K, Biomass Bioenergy, 2008, 32(12), 1274-1278.DOI: 10.1016/j.biombioe.2008.005.

116. Zeng J, Du W, Liu X, Liu D and Dai L, J Mol Catal B Enzymatic., 2006, 43(1-4), 15-18.

117. Masakazu Toda, Atsushi Takagaki, Mai Okamura, Junko N. Kondo, Shigenobu Hayashi, Kazunari Domen and Michikazu Hara, Nature, 2005,438,178. 


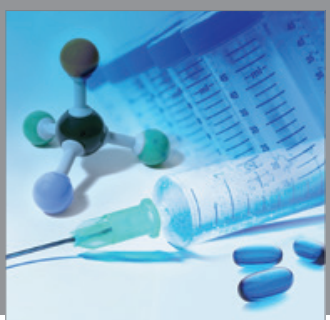

International Journal of

Medicinal Chemistry

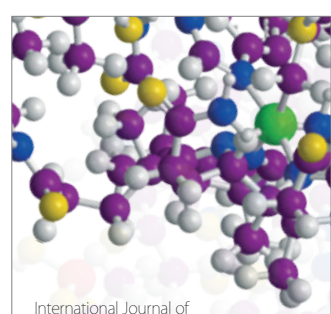

Carbohydrate Chemistry

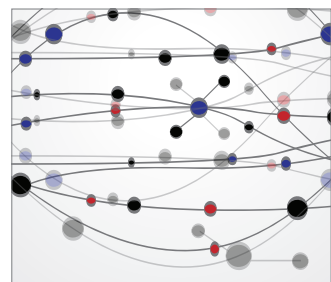

The Scientific World Journal
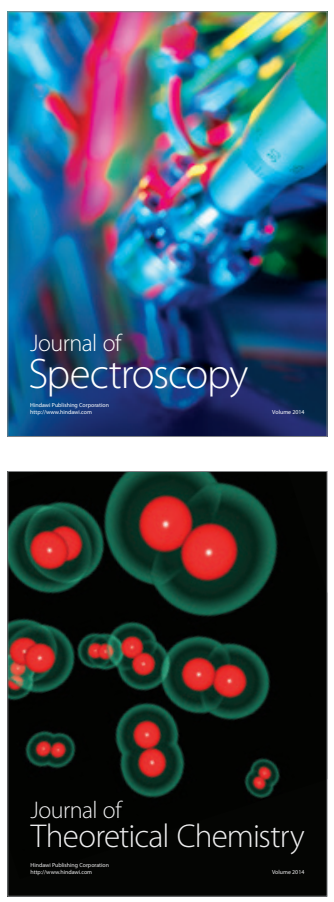
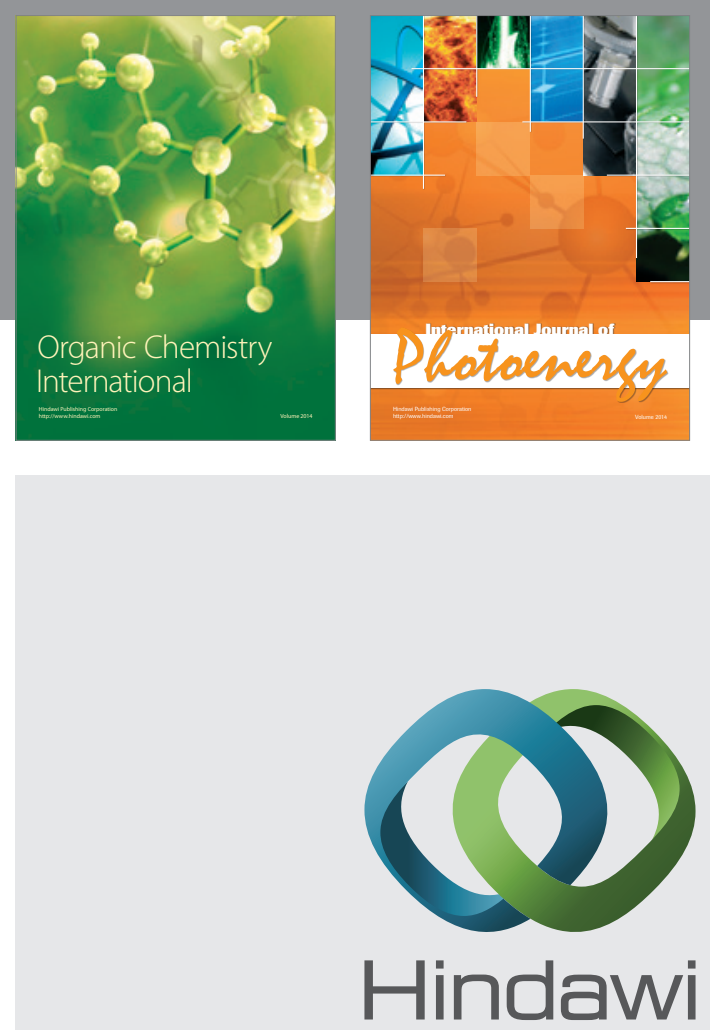

Submit your manuscripts at

http://www.hindawi.com
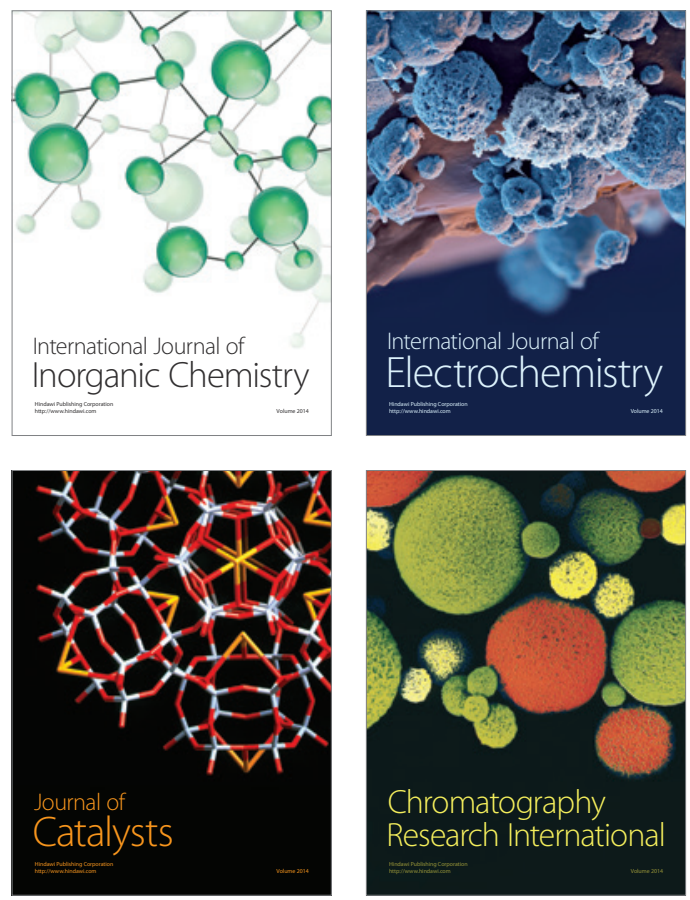
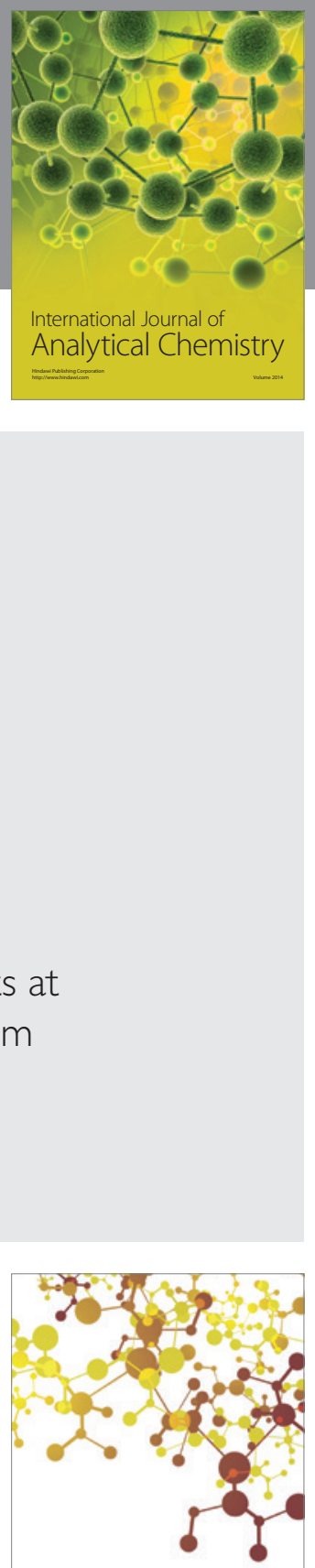

Journal of

Applied Chemistry
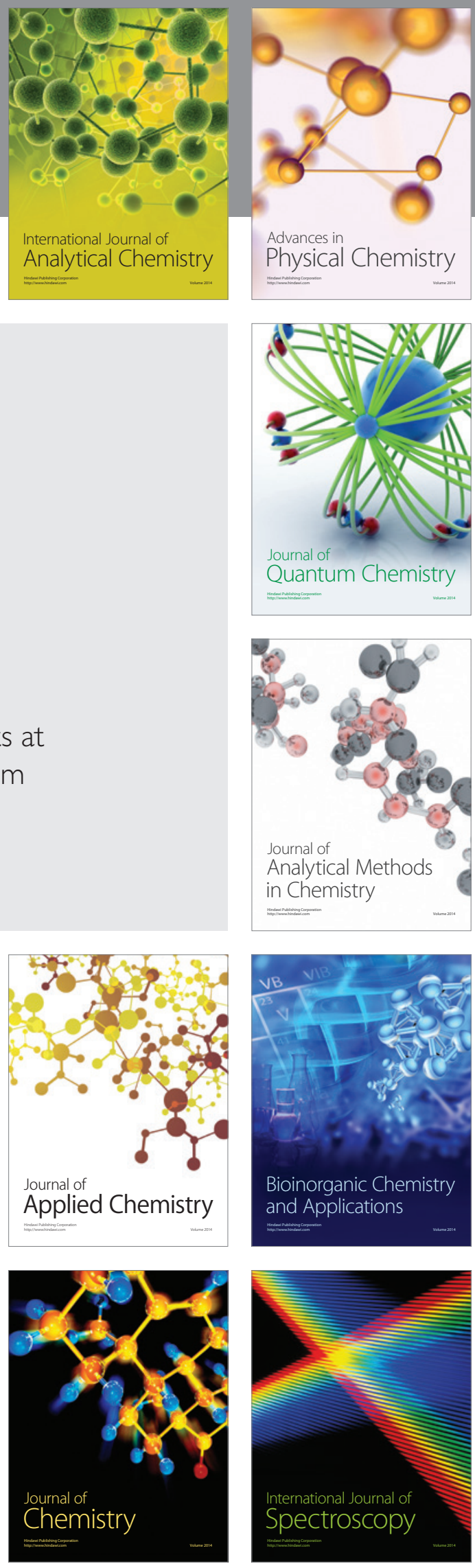